УДК 577-(07.07):378.4

\title{
МЕТОДОЛОГІЧНІ АСПЕКТИ ВИКЛАДАННЯ ЕЛЕКТИВНОГО КУРСУ “СУЧАСНІ ПРОБЛЕМИ МОЛЕКУЛЯРНОЇ БІОЛОГІї” У ВИЩІЙ МЕДИЧНІЙ ШКОЛІ
}

\author{
Т. І. Шевчук, Р. П. Піскун, С. М. Горбатюк, О. О. Ніколаєнко \\ Вінницький наџіональний медичний університет імені М. І. Пирогова

\begin{abstract}
METHODOLOGICAL ASPECTS OF TEACHING THE ELECTIVE COURSE “MODERN PROBLEMS OF MOLECULAR BIOLOGY” AT A HIGHER MEDICAL INSTITUTION
\end{abstract}

\author{
T. I. Shevchuk, R. P. Piskun, S. M. Horbatiuk, O. A. Nikolayenko \\ Vinnytsia National Medical University by M. I. Pyrohov
}

\begin{abstract}
У даній статті розглядаються особливості методології викладання елективного курсу “Сучасні проблеми молекулярної біології” на кафедрі медичної біології. Досліджується процес отримання знань і умінь 3 молекулярної біології і вказується необхідність застосування сучасних методик викладання з метою удосконалення якості професійної підготовки майбутніх лікарів.
\end{abstract}

The main characteristics of methods of teaching the elective course "Modern problems of molecular biology" at the Modern Biology Department are reviewed in the article. The process of knowledge and skills gaining in molecular biology is studied. The necessity of application of modern methods of professional preparation of future doctors is emphasized.

Вступ. Сьогодні відмічається бурхливий розвиток молекулярної біології, яка ставить перед собою завдання пізнання природних явищ життєдіяльності шляхом вивчення біологічних об'єктів і систем на молекулярному рівні. За останні 10-15 років в галузі молекулярної біології та генетики було зроблено революційні відкриття, які дозволили вивчити етіологію та патогенез найпоширеніших захворювань людини на молекулярно-генетичному рівні, розробити високочутливі методи діагностики, визначити підходи до лікування і профілактики багатьох патологій людини [1].

На сьогодні суттєво розширились наші уявлення про структуру та функціонування генома, стали відомі механізми матричного синтезу і біосинтезу білків, механізми регуляції активності генів в онтогенезі людини, проведене секвенування генома людини та інших ссавців, можливе ізолювання, хімічний і біологічний синтез певних генів поза організмом, а також перенесення генів 3 одного організму в інший.

Ці та інші відкриття створили реальну базу для розробки методів молекулярної діагностики, патогенетичного та етіотропного лікування не лише спад- кових патологій людини, а й мультифакторних, інфекційних, онкологічних. Це також сприяє подальшому прогресу таких напрямків, як онкогенетика, фармакогенетика i екогенетика. Все більшого поширення набувають технології, розроблені на основі об'єднання досягнень інформатики і молекулярної генетики так звані мікрочіпові технології [2] .

Вказані фактори зумовлюють необхідність впровадження такої дисципліни, як молекулярна біологія, у навчальний процес у вищому медичному закладі, a також вказують на потребу отримання студентамимедиками сучасних знань, які не лише розширюють загальну освіченість, але й дадуть можливість використовувати їх у майбутній лікарській практиці.

Основна частина. Завданням дослідження $\epsilon$ вдосконалення викладання молекулярної біології 3 метою підвищення якості професійної підготовки майбутніх лікарів.

Об'єктом педагогічного методичного дослідження є процес набування знань, вмінь і навичок з молекулярної біології студентами, що навчаються на першому курсі Вінницького національного медичного університету.

(ㄱ Т. І. Шевчук, Р. П. Піскун, С. М. Горбатюк, О. О. Ніколаєнко 
Курс за вибором "Сучасні проблеми молекулярної біології” розроблений для вищих медичних навчальних закладів III - IV рівнів акредитації і включений в навчальний план підготовки фахівців за спеціальностями "Лікувальна справа", "Педіатрія" та "Медико-профілактична справа". Його вивчення здійснюється на I курсі у вигляді окремої дисципліни. Навчальна програма елективного курсу включає 90 годин, 3 них 14 годин практичних занять, 16 годин лекцій і 60 годин самостійної роботи студентів [3]. На кафедрі медичної біології Вінницького національного медичного університету ім. М. І. Пирогова вивчення елективного курсу “Сучасні проблеми молекулярної біології” було вставлено в графік між другим і третім модулем основної дисципліни "Медичної біології", оскільки даний курс базується не лише на знаннях, отриманих студентами у загальноосвітній школі, а й на попередньо вивчених розділах цитології та медичної генетики [4].

Для успішного забезпечення навчального процесу співробітниками кафедри підготовлені необхідні матеріали методичного забезпечення занять. 3 цією метою розроблені тексти лекцій, які розкривають в повному обсязі проблемні питання відповідних розділів згідно з програмою. Викладення лекційного матеріалу супроводжується мультимедійною презентацією, що покращує сприйняття інформації. До кожного практичного заняття створені методичні вказівки $з$ урахуванням необхідних моментів, що забезпечують педагогічно грамотну організацію навчального процесу на всіх його етапах.

Високий рівень мотивації студентів до теми $€$ важливою умовою сприйняття, запам'ятовування, осмислення навчального матеріалу і подальшого його використання у професійних ситуаціях. Тому викладач повинен володіти переконливими даними, що свідчать про значимість теми, iї роль і місце в подальшій професійній діяльності. Саме з актуальності теми починається кожна методична розробка.

Важливим методичним моментом $є$ постановка навчальних цілей заняття, які мають буги нерозривно пов'язані з позитивною мотивацією. Навчальні цілі залежно від рівня засвоєння поділяються на чотири групи. На першому рівні студент повинен бути спроможним впізнавати матеріал при повторному сприйманні, при цьому повноцінного відтворення матеріалу не передбачається. Методом контролю на першому рівні $€$ використання тестів першого рівня складності 3 одиничною вибірковою відповіддю. Другий рівень засвоєння передбачає детальне відтворення змісту теоретичного матеріалу та використання його в рішенні типових задач. Для контролю другого рівня використовують тести із множинним вибором, або тести “на підстановку” чи з відповіддю, що сама формулюється, або тести, що передбачають визначення правильної послідовності дій, або тести на знаходження співвідношення між елементами двох рядів. Також методом контролю засвоєння знань другого рівня $€$ задачі другого рівня (типові). Третій рівень передбачає формування системи професійних вмінь та навичок і досягається шляхом тренінгу та рішенням нетипових ситуаційних задач. На четвертому (творчому) рівні частіше має місце суб' єктивна творчість, яка полягає у самостійному відкритті студентом нових для нього, але вже відомих науці, даних [5].

Для контролю засвоєння матеріалу на кафедрі розроблені тести з одиничною відповіддю (тести вихідного рівня), тести 3 множинним вибором, а також тести кінцевого рівня знань, які виконують не лише контролюючу функцію, а й навчальну. Створені задачі другого та третього рівнів також мають активну пізнавальну функцію, оскільки утримують певні вихідні дані, які поглиблюють інформацію, створюючи передумови для правильного вибору рішення конкретної ситуації.

До кожного практичного заняття здійснений відбір та структурування змісту навчального матеріалу на основі виділення основних його елементів і визначений логічний зв' язок між цими елементами. Так, зміст матеріалу заняття поділений на інформаційні блоки, а кожний блок в свою чергу складається з головних елементів. Крім того, в кожній методичній розробці обов'язково наявні схеми логічної структури змісту теми заняття, які є графічним відображенням основних змістовних елементів теми ілогічних зв' язків між ними. Такі схеми дозволяють краще осмислити і зафіксувати в пам'яті основний матеріал i, при необхідності, його деталізувати або доповнити.

Організаційна структура практичного заняття передбачає наявність трьох його етапів: підготовчого, основного і заключного. Підготовчий етап включає в себе організаційні заходи, постановку навчальних цілей, створення позитивної пізнавальної мотивації та контроль теоретичної і практичної підготовки за темою заняття. Це досягається шляхом перевірки вихідного рівня знань за допомогою тестів та усного обговорення теоретичних питань у вигляді дискусії.

Важливу роль у професійному становленні майбутнього медика відіграє основний етап, оскільки саме на цьому етапі формується система професійних навичок і вмінь. Для забезпечення даного етапу навчання розроблені задачі різних рівнів складності, а 
також алгоритми та інструкції до самостійної навчально-дослідницької роботи студентів.

Заключний етап практичного заняття передбачає контроль і корекцію рівня професійних умінь і навичок шляхом перевірки індивідуальних програмованих завдань. Крім того, даний етап включає оцінювання успішності студентів та визначаються завдання для самостійної теоретичної підготовки 3 наступної теми.

Самостійна робота студентів займає вагому частку при вивченні молекулярної біології. Основною формою самостійної роботи $є$ написання рефератів на задану тематику, або висвітлення тих питань, які найбільше зацікавили студента в процесі вивчення предмета. Для виконання такої роботи студент повинен самостійно поглиблено вивчити певну проблему, опрацювати багато літературних джерел, правильно відібрати матеріал, підготувати доповідь та створити ілюстративний матеріал у вигляді прозірок чи слайдів. Така позааудиторна діяльність нерідко виливається в цікаву студентську наукову роботу, яка

\section{Література}

1. Медицинская генетика / под ред. Н. П. Бочкова. - М. : Майстерство, 2001.-525 с.

2. Медична генетика : підручник для вузів / В. М. Запорожан, Ю. І. Бажора, А. В. Шевеленкова, М. М. Чеснокова. Одеса : Одес. держ. мед. університет, 2005. - 260 с.

3. Сучасні проблеми молекулярної біології. Програма навчальної дисципліни для студентів вищих медичних навчальних закладів III -IV рівнів акредитації. - Київ, 2005. - 15 с. не обмежується виступом на засіданні науково-дослідного гуртка кафедри, а доповідається на студентських науково-практичних конференціях, публікується в журналах чи збірниках.

Висновки. Таким чином, в умовах бурхливого розвитку молекулярної біології, біотехнології та генетики впровадження в навчальний план підготовки майбутніх медиків елективного курсу “Сучасні проблеми молекулярної біології” $є$ необхідним і логічним. Для підвищення якості професійної підготовки лікарів, для формування профілактичного мислення необхідна правильна організація проведення практичного заняття, вироблення у студентів мотивації до вивчення предмета, використання різних форм і методів навчання, забезпечення наочними матеріалами, створення орієнтовних карт для самостійної роботи 3 літературою. Завдяки вдосконаленим методикам викладання студенти набувають необхідних знань та умінь з молекулярної біології, які знайдуть своє застосування в майбутній лікарській практиці.

4. Викладання медичної генетики в медичному вузі в світлі Болонського процесу / Р. П. Піскун, О. О. Ніколаєнко, А. А. Ващук [та ін.] // Фактори експериментальної еволюції організмів : збірник наук. пр. - Київ, 2010. - С. 494 499.

5. Мілерян В. С. Методичні основи підготовки та проведення навчальних занять в медичних вузах (методичний посібник) / В. С. Мілерян. - Київ : Хрещатик, 2006. - 80 с. 